\title{
Experimental Analysis of a Stand-alone Wind-photovoltaic Hybrid System in the Sahara Desert
}

\author{
R. Maouedj ${ }^{1 *}$, M. Benmedjahed ${ }^{1}$, D. Saba ${ }^{1}$, A. Mamemri ${ }^{1}$, B. Barbaoui ${ }^{1}$, S. Bezari ${ }^{2}$ \\ ${ }^{1}$ Unité de Recherche en Energies renouvelables en Milieu Saharien URERMS, Centre de Développement des Energies \\ Renouvelable CDER, Adrar 01000, Algeria \\ ${ }^{2}$ Unité de Recherche Appliquée en Energies Renouvelables, URAER, Centre de Développement des Energies Renouvelables, \\ CDER, Ghardaïa 47133, Algeria
}

Corresponding Author Email: ra_maouedj@yahoo.fr

https://doi.org/10.18280/ejee.210114

Received: 13 December 2018

Accepted: 9 January 2019

\section{Keywords:}

hybrid system, wind, photovoltaic,

battery, load

\begin{abstract}
The present paper discusses the feasibility study of an autonomous hybrid PV-Wind power system used for public electrification in the city of Adrar- South of Algeria, with an average consumption of $3445 \mathrm{Wh} /$ day.

The system includes a $1 \mathrm{KW}$ of PV arrays ( $78 \%$ solar energy penetration), one wind turbine of $900 \mathrm{~W}(22 \%$ wind energy penetration), 16 unit batteries (12V-100Ah) and $800 \mathrm{~W}$ sized power converters.

The main source of power to the energy system is photovoltaic panels, whereas, wind generators are the supported additional sources.
\end{abstract}

\section{INTRODUCTION}

The transition of the energy sector in the World towards sustainability is one of the biggest challenges of the 21 st century [1]. In 2014, World production marketed energy was 13045 Mtep, with only $9 \%$ from renewable sources [2-3]. In 2035 , the primary energy demand in the world will be close to 17 billion Gtep. $18 \%$ of this demand will be met through renewable sources [1].

Algeria is highly dependent on fossil fuels. Oil and natural gas account for more than $98 \%$ of primary energy demand. Despite that, the country has excellent solar power potential and a considerable wind resource. For that Algeria has incorporated into its energy policy issues of sustainable development and meet the national demand, through a program of development of renewable energy for the period 2011-2030, aspiring to eventually produce $40 \%$ of the national electricity consumption from solar and wind power sectors [4-5].

To meet this program, the government has outlined the following plans for [6-8]:

Short term (2010-2013): Installation of $110 \mathrm{MW}$.

Medium term (2014-2015): Installation $650 \mathrm{MW}$.

Long term (2016-2020): Installation $2600 \mathrm{MW}$.

An additional capacity of approximately $12000 \mathrm{MW}$ is planned for installation by 2030 [6-8].

This paper aims to present and to discuss the experimental results of a stand-Alone Wind- Photovoltaic Hybrid System in the city of Adrar- South of Algeria used for public electrification, with an average consumption of $3445 \mathrm{Wh} /$ day.

\section{THE HYBRID SYSTEM DESCRIPTION}

The proposed prototype in this paper consists of:

(1). $1 \mathrm{~kW}$ photovoltaic solar panels $(250 \mathrm{~W})$;

(2). Wind turbine of $900 \mathrm{~W}$ (Whisper100);
(3). 16 unit batteries (SP12V-100Ah);

(4). Battery charging and discharging controller Steca Tarom 245-24V;

(5). Victron energy 800 inverter.

The experimental prototype of PV-Wind hybrid system has been installed in the Renewable Energy Research Unit (URER-MS), Adrar [9-10].

During the testing period, from 02 to 08 March 2017, the following data were regularly measured:

(1). Solar radiation (using CM 11 pyranometer).

(2). Wind speed (at a $10 \mathrm{~m}$ above ground level).

(3). Photovoltaic output power.

(4). Wind turbine output power.

(5). Load profiles.

\section{LOAD PROFILES ANALYSIS}

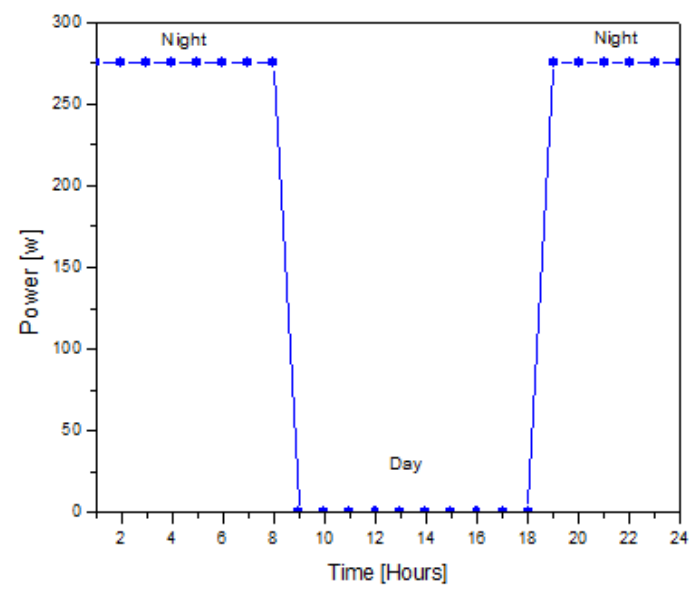

Figure 1. The Hourly profile of the considered load 
Table 1. Calculated energy consumption

\begin{tabular}{lccc}
\hline Appliance & $\begin{array}{c}\text { Power } \\
{[\mathrm{W}]}\end{array}$ & $\begin{array}{c}\text { Number of used } \\
\text { hours/ day } \\
\text { [hours] }\end{array}$ & $\begin{array}{c}\text { Used energy } \\
\text { /day } \\
\text { [Wh] }\end{array}$ \\
\hline Lighting & 265 & From 19 H to 07 H & 3445 \\
\hline
\end{tabular}

The statistical data of electricity consumption of the load charges (DC and AC) are collected every 30 second and integrated over each day [11].

$E_{d}=\sum_{i=1}^{n} I_{n} V_{n} D_{n}$

where:

Ed: total energy demand.

In: the current;

Vn: the voltage;

Dn: duty cycle of each appliance used in one day.

The average daily consumption is calculated as
$3445 \mathrm{Wh}$ /day according to Eq. (1) and the hourly profile of the load charges is shown in Figure 1.

\section{RESULTS AND DISCUSSION}

The system performances were studied, from 02 to 08 March 2017. Figures 2 to 8 show the variation of the measured data for solar radiation, wind speed, voltage and state of charge SOC of the battery bank, PV and wind energy output as a function of time.

The hourly variation of solar radiation and PV output powers are shown respectively in Figure 2 and 5, it can be observed that a distinct increase of PV output powers has been observed since 9:00h with the increase of solar radiation.

The hourly variation of the wind speed as well as the wind turbine output powers are shown respectively in Figure 3 and 6 . It can be observed that average wind speed is higher between 10:00H and 16:00H, while lower values are obtained during the rest of the day.
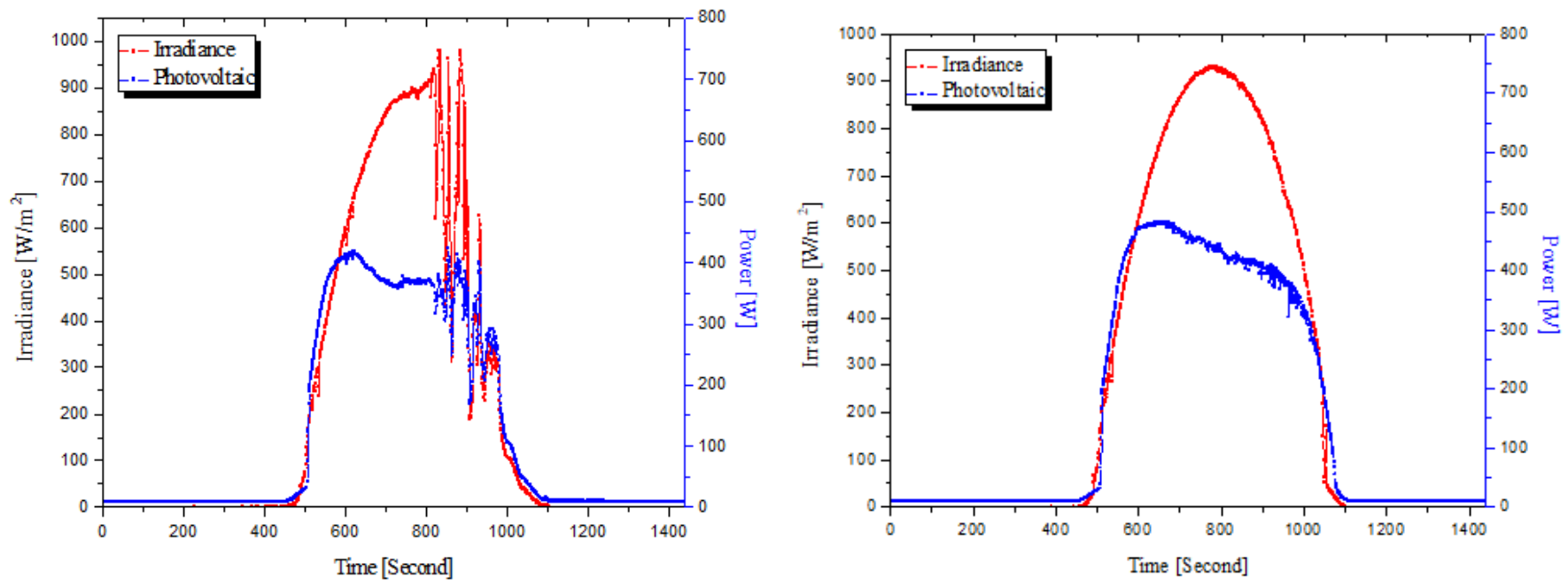

Figure 2. Variation of solar radiation and PV output power: a) 02 March 2017; b) 08 March 2017
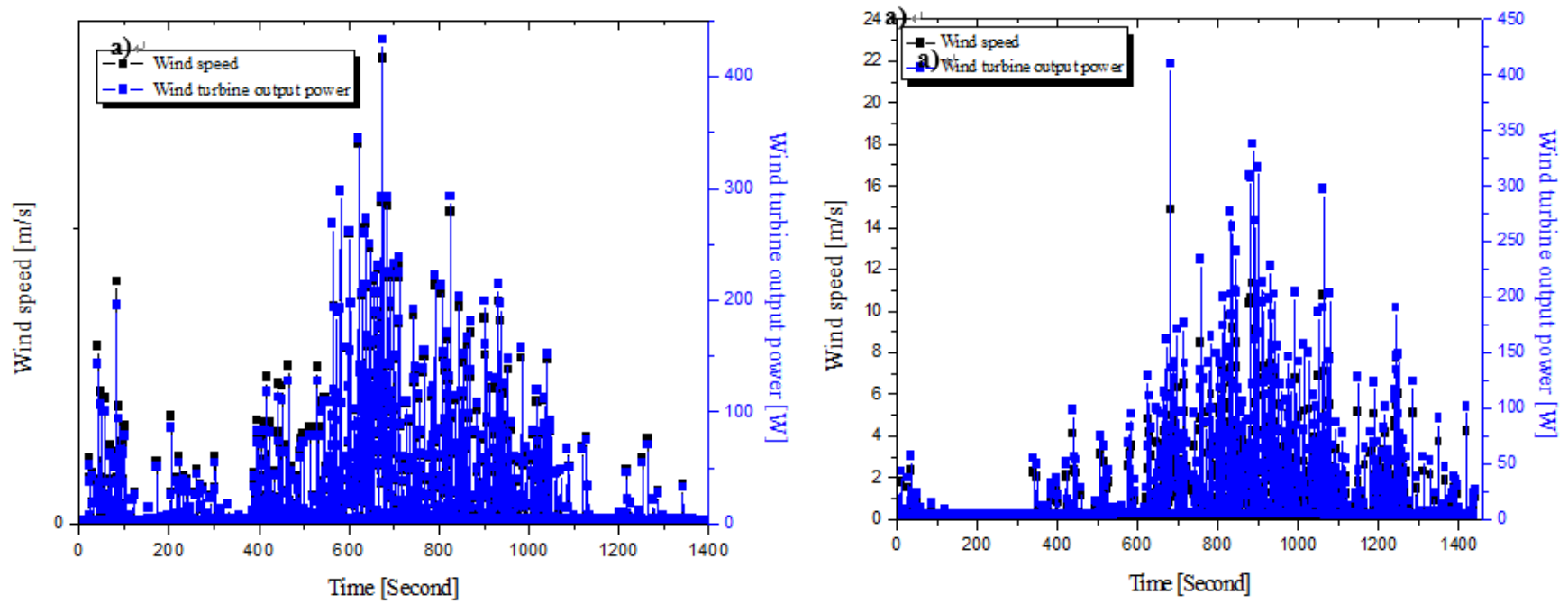

Figure 3. Variation of wind speed and wind turbine output power: a) 02 March 2017; b) 08 March 2017 

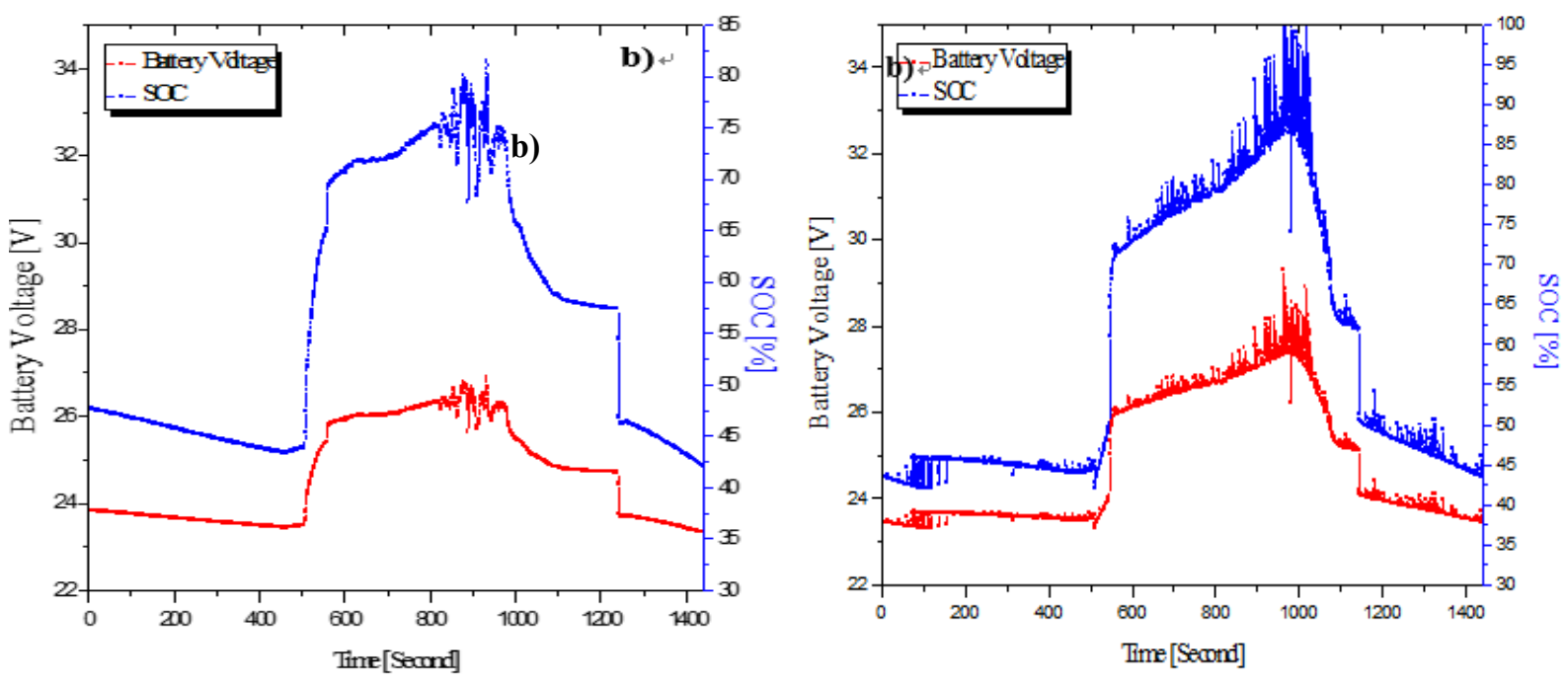

Figure 4. Variation of voltage and SOC of the battery bank during charge and discharge time: a) 02 March 2017; b) 08 March 2017
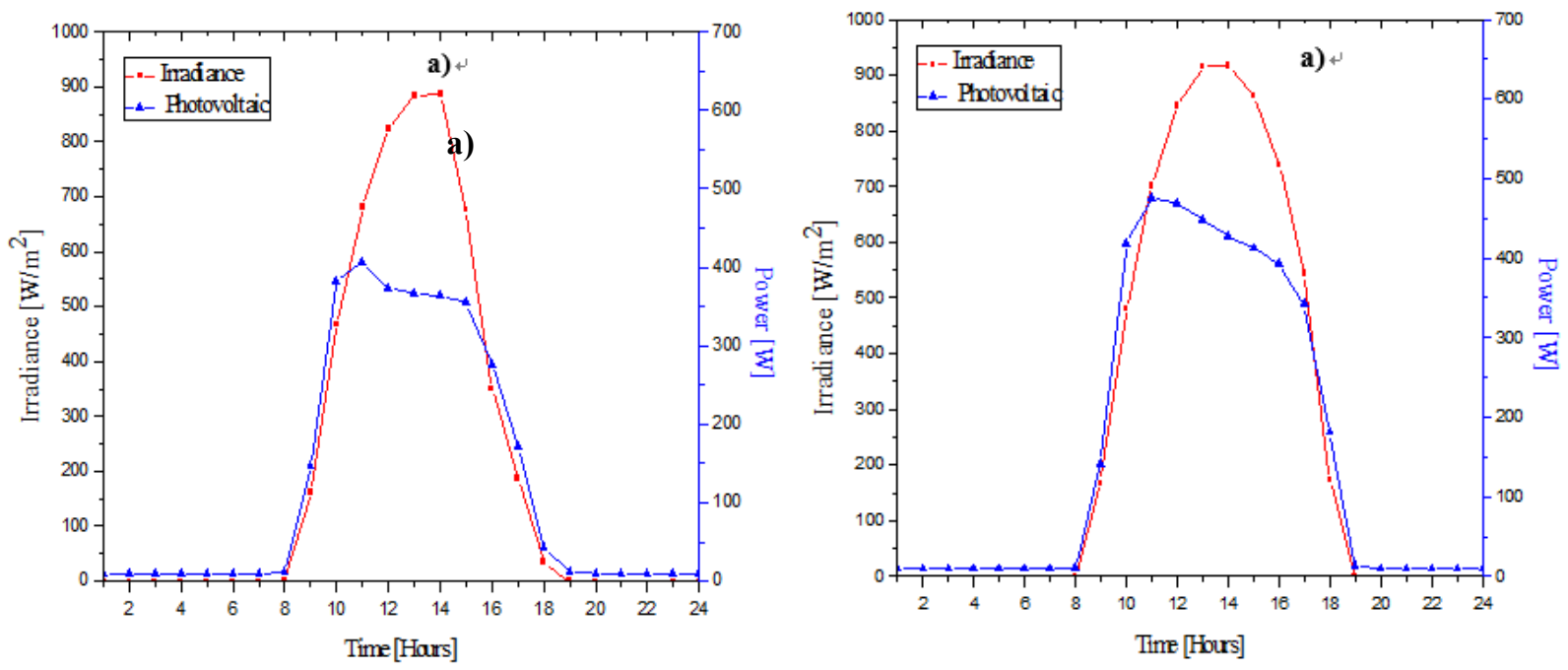

Figure 5. Global irradiance on the inclined plan and PV output power: a) 02 March 2017; b) 08 March 2017
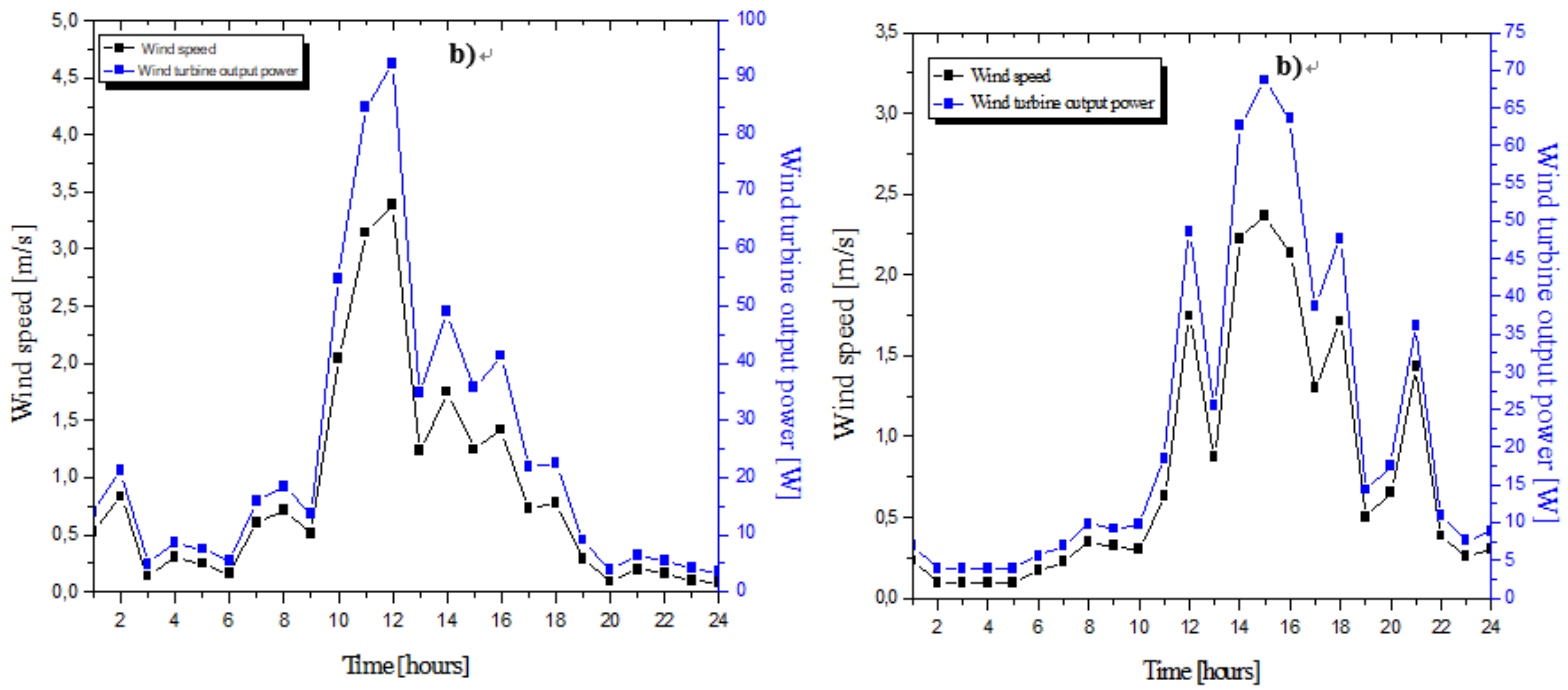

Figure 6. Variation of wind speed and wind turbine output power: a) 02 March 2017; b) 08 March 2017 

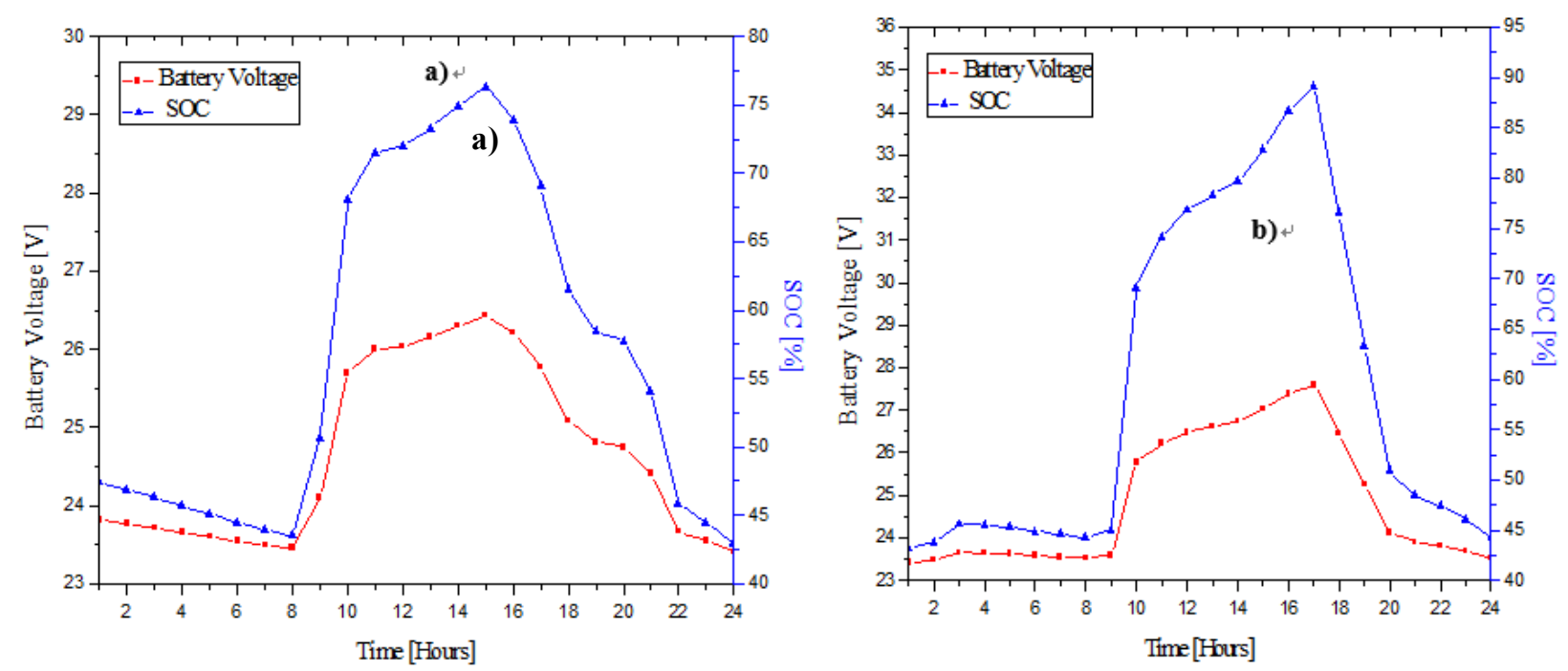

Figure 7. Variation of voltage and SOC of the battery bank: a) 02 March 2017; b) 08 March 2017

From the Figure 4 and Figure 6, the following points can be observed:

(1). The hourly-mean battery SOC is much higher during the hour's 11:00h-18:00h than the rest of the day.

(2). The peaks of the SOC (\%) varied between 16:00h and 17:00h (Energy productions of the system were maximum).

(3). A distinct increase of battery SOC has been observed since 10:00h with the increase of solar radiation.

(4). For all days, the SOC varied between a SOCmax of $41 \%$ and a SOCmin of $94 \%$.

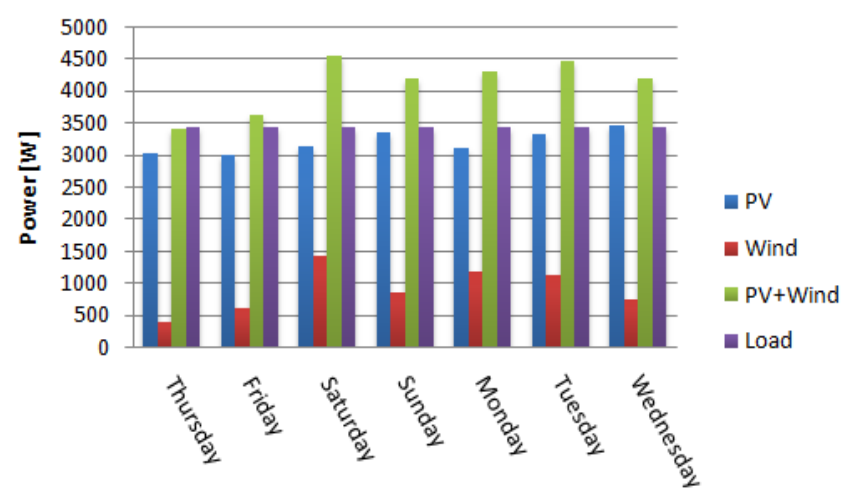

Figure 8. Daily variation of load, power contribution by wind, solar PV and hybrid power systems (From 02 to 08 March 2017)

Figure 8 shows that the total generated power by the studied system meets the load at any time of the day.

Table 2. Energy contribution by each source

\begin{tabular}{lcccccc}
\hline & PV & Wind & $\begin{array}{c}\text { PV }+ \\
\text { Wind }\end{array}$ & $\begin{array}{c}\text { PV } \\
(\%)\end{array}$ & $\begin{array}{c}\text { Wind } \\
(\%)\end{array}$ & $\begin{array}{c}\text { Total } \\
(\%)\end{array}$ \\
\hline Thursday & 3015,3 & 386,7 & 3402,0 & 89 & 11 & 100 \\
Friday & 3013,1 & 613,1 & 3626,2 & 83 & 17 & 100 \\
Saturday & 3124,4 & 1427,8 & 4552,2 & 69 & 31 & 100 \\
Sunday & 3344,2 & 858,0 & 4202,2 & 80 & 20 & 100 \\
Monday & 3110,1 & 1191,0 & 4301,1 & 72 & 28 & 100 \\
Tuesday & 3324,3 & 1137,9 & 4462,3 & 74 & 26 & 100 \\
Wednesday & 3452,2 & 753,1 & 4205,3 & 82 & 18 & 100 \\
Daily Moy. & 3197,7 & 909,7 & 4107,4 & 78 & 22 & 100 \\
\hline
\end{tabular}

The Table 2 gives the energy contribution of solar PV and wind systems of total energy production by the hybrid system. As seen in the previous table, $78 \%$ of the energy is supplied by the PV system and $22 \%$ is supplied by the wind turbine.

The average daily power contribution of the PV system to the hybrid power system ranges from a minimum $69 \%$ on Saturday to maximum $89 \%$ on Thursday.

However, the wind power contribution varied between a minimum of a maximum of $11 \%$ on Thursday and $31 \%$ on Saturday.

\section{CONCLUSION}

In this article, we present the experimental results of the operation of a hybrid PV-Wind-battery system in the city of Adrar- Sahara Desert of Algeria used for public electrification, with an average consumption of $3445 \mathrm{Wh} /$ day.

From the results obtained during the system operating tests, we can note that:

(1). The battery SOC is dominated by the production of the PV array.

(2). The contribution of solar photovoltaic and wind in the energy production depend to the weather conditions (the intensity and the duration of availability of this energy sources).

(3). The energy produced is sufficient to supply the load demands at all times due to the complementarities between the two renewable energy sources.

(4). At any time of the day, the SOC is superior at the permissible minimum value of the SOC (SOCmin $=20 \%$ of SOC).

(5). It is found that the use of renewable energy sources is feasible to solve the rural electricity provision in the isolated rural areas in Adrar city (South of Algeria).

\section{REFERENCES}

[1] Projet ER2E. (2013). Promotion des Energies Renouvelables et de l'Efficacité Energétique. Réalisations du projet Promotion des Energies Renouvelables et de l'Efficacité Energétique en Tunisie. 
[2] BP Statistical Review of World Energy 2015, (2015).

[3] https://fr.wikipedia.org/wiki/Ressources_et_consommat ion_\%C3\%A9nerg\%C3\%A9tiques_mondiales

[4] Ministry of Energy and Mines. (2007). Guidelines to renewable energies. Algeria.

[5] Ministry of Energy and Mines. (2011). Renewable Energy and Energy Efficiency Program. Designed and printed by SATINFO, Sonelgaz Group Company.

[6] Solar energy Northern Africa 2017. (2017). Unlocking solar capital Africa. Abidjan, Côte d'Ivoire: 25-26.

[7] Oxford Business Group. The Report: Algeria 2013. ISBN: $1907065938,9781907065934$.

[8] Nachmany M, Fankhauser S, Davidová J, Kingsmill N, Landesman T, Roppongi H, Schleifer P, Setzer J, Sharman A, Singleton CS, Sundaresan J, Townshend T. (2015). Climate change legislation in Algeria. The 2015 Global Climate Legislation Study. A Review of Climate
Change Legislation in 99 Countries.

[9] Maouedj R, Mammeri A, Draou, MD, Benyoucef B, (2014). Performance evaluation of hybrid PhotovoltaicWind power systems. Energy Procedia 50: 797-807. http://dx.doi.org/10.1016/j.egypro.2014.06.098

[10] Maouedj R, Mammeri A, Draou MD, Benyoucef B. (2015). Techno-economic analysis of a standalone hybrid photovoltaic-wind system. Application in electrification of a house in Adrar region. Energy Procedia 74: 1192-1204. http://dx.doi.org/10.1016/j.egypro.2015.07.762

[11] Panayiotou G, Kalogirou S, Tassou S. (2012). Design and simulation of a PV and a PV-Wind standalone energy system to power a household application. Renewable Energy 37: 355-363. http://dx.doi.org/10.1016/j.renene.2011.06.038 